\title{
BELTS OF THE PEREIASLAV AREA OF THE XIX - FIRST HALF OF THE XX CENTURY (BY THE MATERIALS OF THE NATIONAL HISTORICAL-ETHNOGRAPHIC RESERVE «PERIASLAV»)
}

\section{Natalia Shkira ${ }^{1}$}

DOI: https://doi.org/10.30525/978-9934-588-11-2_38

In museum collections, special attention is paid to things that are of everyday use, but not always understood in our time. In the age of innovative technologies, powerful industrialization and the creation of large transcorporations, we want to look back into the past and understand how in the old days most things of use were made at home by themselves, with the help of not sophisticated instruments and mechanisms, attaching great importance to ornaments, a sign system that included a large number of signs, symbols, motifs, and was a true charm.

One of the important elements of human civilization was traditional clothing, it was distinguished by sophistication and adapted perfectly to the living and climate conditions. Historically, traditional forms of tailoring and manufacturing of household apparel and household goods have been passed down from generation to generation and supported by the common opinion of the community. The main spinning fibers of the Ukrainians have long been flax, hemp and wool for a long time.

The stock collection of Pereyaslav National Historical and Ethnographic Reserve (hereinafter referred to as NHER «Pereyaslav») has a large group of «T»- exhibits, fabrics collected in the 1950s and 1990s, in different regions of Ukraine: shirts, belts, outerwear (summer, autumn, winter), shoes. The collection was formed rather spontaneously, only a part of the description of the objects tells about the masters, the names of the samples, the manufacturing techniques and the place of residence [1].

Favorite motifs are stylized bunches of grapes, stars, nightingale eyes, periwinkle, cuckoo, hops, and others. The pattern weaving technique allowed us to vary the combination of three colors of yarn - white, black, red and create many geometric patterns - simple or toothed strip, rhombuses, squares.

The collection of belts consists of over five hundred female and male artifacts of the 19th - first half of the 20th century, collected in different regions of Ukraine. Conditionally they can be divided into two groups - knitted and woven.

The largest part of the collection was collected by museum workers in the $60-80 \mathrm{~s}$ of the twentieth century in Poltava and Cherkasy region, a large number of belts were discovered and purchased in Chernihiv and Kyiv region, especially in the collections of belts made in Pereyaslav region (about one hundred units).

In the nineteenth and first half of the twentieth century, homemade woolly peasant belts, home-dyed in bright red, yellow, green, beet, orange, pink, and raspberry, were widespread in all regions of Ukraine, including the Pereyaslav Region.

\footnotetext{
${ }^{1}$ National Historical and Ethnographic Reserve «Pereiaslav», Ukraine
} 
The poorer part of the population wore everyday unpainted belts, and even just a hoop or rope. The color often depends on the material, some of the studied artifacts have a natural color of wool, white, gray, brown and black.

Belts and edges were made at home, color and pattern were selected for other items of clothing. Most of the collected textiles use artistic framing and complex symbolism: triangles, rhombuses, rosettes, stripes, floral ornaments, petal flowers, leaves, etc. that were typical of folk clothing.

Museum items have local and regional names of symbols, which is an important material for the scientific processing of artifacts. The ends of the belts and edges are ornamented equally, although there are separate instances where the pattern is different: on the one side - vegetable, on the other - geometric. Belts differ in size. As a rule, the waistband can be double-cropped, the average length of the belt is 200-220 centimeters. In the region under study, hand-woven, home-dyed wool belts adorned at the ends of dots and tassels predominated.

In the edges, bright colors were used more often, geometric ornamentation dominated in decoration: stripes, rhombuses, triangles with local names. Among the rarities objects of bright red should be highlighted.

In addition to homemade, there were extended belts made by urban artisans. Beginning in the second half of the 19th century, home-made belts were replaced with factory ones. In 1902, a Zemsky weaving workshop was opened in Pereyaslav, Kyiv region. Here tapestries, towels, tablecloths, belts, edges and so on were made. In 1917, an art and industrial school was established at the workshop, which in 1929 was reorganized into a textile art studio. During the occupation, the artel, did not work, but resumed its work in 1944 and was named after him Bohdan Khmelnytsky. From the middle of the twentieth century there was a wide demand for ornamental men's ties, blouses, dresses, belts, tablecloths, curtains, bed linen, etc., which were made at the factory of art products B. Khmelnitsky in Pereiaslav-Khmelnitskyi. Favorite motifs of belts and edges of the factory of art products - stylized ore bunch of grapes, «stars», «nightingale», «periwinkle», «cuckoo», «hops» others.

The pattern weaving technique allowed us to vary the combination of three colors of yarn - white, black, red and create many geometric patterns - simple or toothed strips, rhombuses, squares.

A considerable part of the collection needs attribution - a set of scientific measures by which authorship is defined, a sertain school, a sertain family to the subject belongs, the time of creation of the object and the characteristics of the artifact (material, technique, size, color, source of income, purpose, chronology) are specified and geography). Only a small part of the material that can be presented without repair and restoration is well preserved and exposed. Therefore, the selection of objects that require special storage conditions, photo-fixing - is an important part of museum activity.

Only a small fraction of the material that can be presented without repair and restoration is well preserved and exposed. Therefore, the selection of objects that require special storage conditions, photo-fixing - is an important area of museum activity. A detailed study of ornamentation, coloring, techniques of making belts 
stored in the stock collection of the National Historical and Ethnographic Reserve «Pereiaslav» is important not only for fashion designers, but also for anyone involved in the important work - the revival and preservation of the artistic and cultural heritage of the Ukrainian people.

\section{References:}

1. Materials of stock inventory books «T» №№ 1-19 of the National Historical-Ethnographic Reserve «Pereiaslav» (code «T»- «Fabrics», №№ 1-11666). 